Вісник Дніпропетровського університету. Серія: геологія, географія. 2016. 24 (1), 144-150.

Vìsnik Dnìpropetrovs'kogo unìversitetu. Seriâ geologîâ, geographîâ

Dnipropetrovsk University Bulletin. Series geology, geography. 2016, 24 (1), 144-150.

doi: $10.15421 / 111622$

http://geology-dnu.dp.ua

УДК 378 (09)

\title{
25 років з часу відновлення геолого-географічного факультету ДНУ: історія становлен- ня та сьогодення
}

\section{Н. П. Шерстюк, В. В. Безуглий}

Дніпропетровський національний університет імені Олеся Гончара, Дніпропетровськ, Украӥна, e-mail:sherstuknp@inbox.ru

Наведено основні віхи історії створення та становлення геолого-географічного факультету у Дніпропетровському (Катеринославському) університеті. Історія цього факультету почалася 31921 р., коли на базі Інституту теоретичних наук було створене геолого-географічне відділення, яке з 1937 р. перетворилося на потужний факультет. У довоєнні часи геолого-географічний факультет був одним із найбільших в університеті. Його діяльність перервала Друга світова війна. Перед окупацісю Дніпропетровська факультет переїхав до Оренбурга та міст Уралу і Сибіру. Після війни авторитет факультету зростав, країні потрібні були освічені геологи, топографи, метеорологи, гідрологи, мінералоги, вчителі. Однак у 1960 р. через кардинальні реорганізаційні процеси в ДДУ геолого-географічний факультет було закрито, а навчання студентів припинено. Відродження факультету відбулося у вересні 1990 року. Нині геолого-географічний факультет ДНУ імені Олеся Гончара складається з трьох кафедр (фізичної та економічної географії, гідрометеорології та геоекології, геології та гідрогеології), на яких навчаються понад 250 студентів.

Ключові слова: університет, геолого-географічний факультет, кафедра

\section{Years of Geology and Geography Faculty of Oles Hochar DNU Renewal: History of Formation and the Present}

\author{
N.P. Sherstyuk, V.V. Bezugly \\ Oles Honchar Dnipropetrovsk National University, Dnepropetrovsk, Ukraine, e-mail: sherstuknp@inbox.ru
}

The major milestones of Geology and Geography Faculty of Dnipropetrovsk (Katerynoslav) University creation and development is provided. The history of Geology and Geography Faulty of Katerynoslav University started in 1921, when on the basis of the Institute of theoretical sciences Geology and Geography Department was established, which since 1937 became a powerful faculty. In pre-war times, Geology and Geography Department was one of the most powerful ones at the University. It included the largest number of departments (10) in DSU (Dnipropetrovsk State University). Despite all the domestic and economic difficulties before the war, Geology and Geography Faculty was gradually becoming a powerful scientific and educational centre in the region. Regular activities of the Faculty was interrupted by World War II. Before the occupation of Dnipropetrovsk the faculty moved to Orenburg and the other cities of the Urals and Siberia. A lot of teachers and students went to the front on the call or voluntarily. After the war the authority of the faculty was growing as the country needed qualified geologists, topographers, hydrometeorologists, hydrologists, mineralogists and teachers. However, in 1960 because of drastic reorganization processes in DNU, Geology and Geography Faculty was closed and the training of students stopped. The Departments of Geological direction were reorganized and the Department of Geography was transferred to the other faculty and trained only specialists of correspondence form of education. The revival of Geology and Geography Faculty took place in September, 1990. Professor G.V. Pasichny, associate professors V.V. Bogdanovic, I.S. Danilov, I.N. Barg contributed a lot into the development of the Faculty. Doctor of Geographical Sciences, professor G.V. Pasichnyi, a well known paleogeographer in Ukraine, became the Head of the Faculty, that initially consisted of 3 departments (physical and economic geography, geology and hydrogeology). Nowadays Geology and Geography Faculty of Oles Honchar Dnipropetrovsk National University consists of 3 departments (Physical and Economic Geography, Hydrometeorology and Geoecology, Geology and Hydrogeology) where more than 250 students study.

Key words: University, Geology and Geography Faculty, Department. 
Історія геолого-географічного факультету в Катеринославському університеті почалася з 1921 р., коли на базі Інституту теоретичних наук (ITEH), керівником якого був відомий академік Л. В. Писаржевський, було створене геолого-географічне відділення на чолі з проф. Л. Л. Івановим, учнем академіка В. I. Вернадського. Згодом, у 1923-1924 навчальному році відділення було ліквідоване у зв язку з його злиттям із природничим, однак програми і навчальні плани залишилися старими.

Катеринославський університет у скрутні часи становлення радянської влади позбувся статусу університету і отримав назву «Катеринославський вищий інститут народної освіти» (КВІНО), до складу якого увійшли п' ять відділень (математики, природниче, хімії, історії, мови і літератури). У цей період ані геологічні, ані географічні дослідження майже не проводилися.

10 березня 1933 року постановою РНК УСРР «Про організацію на Україні державних університетів» у Дніпропетровську відновлюється діяльність державного університету в складі чотирьох факультетів: фізико-математичного, хімічного, геологічного та біологічного. Відтоді справді настає період розквіту геологічної освіти на Дніпропетровщині. У цьому ж році до складу наукових закладів ДДУ були введені Інститут геології та геофізична лабораторія. В 1935 році з ініціативи Л. Л. Іванова відкрився мінералогічний музей, колекції якого відображали поширення корисних копалин по території України, Уралу, Кавказу, Середньої Азії, Казахстану, Алтаю, Далекого Сходу, Камчатки, Сахаліну тощо.

Із 1937-1938 навчального року розпочалося існування географічного факультету, який мав спільний 3 геологічним факультетом деканат і згодом був перетворений на географічне відділення єдиного геолого-географічного факультету.

Важкі часи політичних репресій кінця $30-\mathrm{x}$ років XX ст. позначилися і на діяльності геолого- географічного факультету. Протягом двох років (1937-1939) не здійснювався набір студентів на геологічне відділення факультету. Причина була традиційною для тих часів - «масове засилля ворогів народу на геологічному відділенні факультету», через що велику кількість викладачів та навіть студентів було репресовано (1). У 1939-1940 навчальному році набір був відновлений, другий і третій курси геологів виділені з відповідних курсів географічного відділення.

У довоєнні часи геолого-географічний факультет був одним із найпотужніших в університеті, в 1940 р. до його складу входила найбільша кількість кафедр у ДДУ - десять (табл. 1).

На геологічному відділені на 1 вересня 1940 року функціонували шість кафедр:

- кафедра петрографії (в. о. зав. каф. доц. Каніболоцький Павло Михайлович);

- кафедра мінералогії (в. о. зав. каф. доц. Виноградова Євгенія Олександрівна);

- кафедра корисних копалин (зав. каф. проф. Танатар Йосип Ісаакович);

- кафедра історичної геології (в. о. зав. каф. доц. Карлов Микола Миколайович);

- кафедра гідрогеології (в. о. зав. каф. доц. Браун Григорій Григорович);

- кафедра геотектоніки та геоморфології (зав. каф. проф. Семененко Микола Пантелеймонович).

На географічному відділенні працювало чотири кафедри:

- кафедра фізичної географії (в. о. зав. каф. проф. Ніколаєв Микола Григорович);

- кафедра економічної географії (в. о. зав. каф. ст. викл. Якубаніс Микола Борисович);

- кафедра геодезії та картографії (в. о. зав. каф. ст. викл. Шеляков Микола Сергійович);

- кафедра трунтознавства (в. о. зав. каф. ст. викл. Стадніченко Василь Георгійович).

Першими деканами об`єднаного факультету

Таблиия 1

Місце геолого-географічного факультету в організаційній структурі ДДУ в 1940-1941 н. р. (за [2])

\begin{tabular}{|l|l|l|l|}
\hline Факультети & $\begin{array}{l}\text { Кількість } \\
\text { кафедр }\end{array}$ & $\begin{array}{l}\text { Kiлькість } \\
\text { професорів }\end{array}$ & $\begin{array}{l}\text { Kiлькість } \\
\text { доцентів }\end{array}$ \\
\hline Геолого-географічний & 10 & 3 & 5 \\
\hline Біологічний & 9 & 5 & 4 \\
\hline Механіко-математичний & 8 & 2 & 6 \\
\hline Фізичний & 6 & 3 & 3 \\
\hline Філологічний & 5 & - & 4 \\
\hline Хімічний & 5 & 3 & 2 \\
\hline Історичний & 2 & - & - \\
\hline Загальноуніверситетьскі кафедри & 6 & - & 3 \\
\hline Усього & 51 & 16 & 27 \\
\hline
\end{tabular}


були призначені проф. М. Г. Ніколаєв, а 31939 р. директор НДІ геології Н.З. Хмарський.

На факультеті були запроваджені єдині типові навчальні плани, жорсткій регламентації піддалися програми з діалектичного та історичного матеріалізму, політичної економії, іноземної мови, військової підготовки, фізичної культури; загальними для всіх спеціальностей факультету були такі предмети як топологія, загальна фізична географія, географія рослин 3 основами ботаніки, географія грунтів 3 основами грунтознавства, географія тварин з основами зоології, історична геологія, картографія, метеорологія, кліматологія, фізична географія СРСР, економічна та політична географія світу.

Однією з вагомих довоєнних проблем у житті геолого-географічного факультету була нестача навчально-виробничих площ. Деякі кафедри і лабораторії навіть не мали окремих кабінетів або кімнат. Були лабораторії, що мали дуже цінне обладнання, однак через відсутність постійних приміщень використовували його невелику частину. Заняття студентів велися в другу і частково в третю зміну. Контингент студентів факультету був потужним і в цілому складав до 15-20 \% від загального по університету (табл. 2). спеціалістами Інституту геології ДДУ досліджували властивості червоно-бурих та інших видів глин як будівельного матеріалу й сировини для виробництва алюмінію, різноманітні рідкісні елементи, генезис графітових родовищ, процес утворення залізних руд, ретельно готували першу карту геологічної та тектонічної будови Дніпропетровської області.

Регулярну діяльність факультету перервала Друга світова війна. Перед окупацією Дніпропетровська факультет переїхав до Оренбурга та міст Уралу і Сибіру. Чимало викладачів та студентів факультету за призовом або добровільно пішли на фронт. Хоробро воювала на полях війни А. П. Дьоміна, учасниця бойових дій на Курській дузі, яка після війни плідно працювала доцентом на кафедрі географії ДДУ. Студент геолого-географічного факультету Михайло Носовський пройшов шлях від топографа артилерійського полку до помічника начальника політвідділу дивізії, нагороджений орденами Червоної Зірки і багатьма медалями. Після мобілізації з лав Радянської Армії він повернувся до Дніпропетровська і продовжив навчання у ДДУ. Тривалий час проф. М. Ф. Носовський був проректором ДДУ і директором Інституту геології ДДУ.

Відразу після визволення Дніпропетровська

Контингент студентів геолого-географічного факультету в 1938-1941 pp. (за [2])

Таблиия 2

\begin{tabular}{|l|l|l|}
\hline Навчальний рік & Кількість студентів ГГФ & \% від кількості в ДДУ \\
\hline $1938 / 1939$ н. p. & 347 & 22 \\
\hline $1939 / 1940$ н. p. & 307 & 16 \\
\hline $1940 / 1941$ н. p. & 307 & 14 \\
\hline
\end{tabular}

Однак, незважаючи на всі побутово-економічні труднощі довоєнних часів, геолого-географічний факультет поступово ставав міцним науковим і навчальним геоосередком у регіоні. 3 лав факультету вийшов ректор (1936-1937), вчений-геолог I. М. Єфимов (репресований у 1937 р.). На посади завідувачів кафедр були запрошені провідні фахівці Дніпропетровщини - проф. Й. І. Танатар (кафедра корисних копалин), проф. М. П. Семененко (кафедра геотектоніки та геоморфології), доц. П. М. Каніболоцький (кафедра петрографії). Викладачі і студенти факультету проводили різноманітні наукові дослідження на теренах тодішнього Радянського Союзу, брали активну участь у роботі розвідувальних експедицій на Кавказі, Уралі, Кольському півострові, у Сибіру, на берегах Північного Льодовитого океану, в Якутії, Алтайському краї, багатьох областях і районах України. Разом із від фашистських загарбників діяльність факультету швидко відновилася. Вже 6 листопада 1943 року в університеті почалися заняття. Перше пробне заняття провели саме на геолого-географічному факультеті. Почався навчальний процес урочисто, за присутності ректора, деканів, громадськості та військового командування [1]. Однак регулярні заняття на факультеті почалися лише 31 січня 1944 року. Умови для освітньої діяльності були вкрай важкими (аудиторії не опалювалися, погане освітлення, відсутність столів та стільців, замість зошитів використовували старі книги та газети, підручників не було...). У перші повоєнні роки навчання продовжили студенти, які не встигли закінчити перший курс у 1941 році.

Певні реорганізаційні заходи на геолого-географічному факультеті відбулися відразу після вій- 
ни, зокрема, деякі кафедри були закриті, а решта об єднані. На 1 вересня 1948 року на факультеті вже залишилося шість кафедр (із 10 довоєнних):

- кафедра геодезії та астрономї (в. о. зав. каф. ст. викл. Шеляков Микола Сергійович);

- кафедра мінералогії та картографії (зав. каф. проф. Танатар Йосип Ісаакович);

- кафедра загальної геологї (зав. каф. доц. Коненков Дмитро Михайлович);

- кафедра історичної геологї та палеонтологї (зав. каф. доц. Приходько Антонина Василівна);

- кафедра економічної географії (зав. каф. доц. Баскін Яків Семенович);

- кафедра фізичної географії (зав. каф. проф. Ніколаєв Микола Григорович).

Після війни авторитет геолого-географічного факультету зростав, країні потрібні були освічені геологи, топографи, метеорологи, гідрологи, мінералоги, вчителі. Тому вступний конкурс на факультет був високим, а попит на його фахівців - значним. Розширювалися й навчально-методичні структури факультету. Так, вдалося облаштувати лабораторії грунтознавства, гідрогеології, оптичного аналізу, мікропалеонтології, створити кабінети геодезії, мінералогії, петрографії, палеонтологіі. На потребу дня змінився й геологічний напрям навчання, стали готувати випускників за фахами «Геологічна зйомка» та «Пошуки корисних копалин». Тісна співпраця здійснювалася 3 Інститутом геології ддУ, у лабораторіях якого студенти факультету досліджували геологічну будову півдня України, займалися розширенням мінерально-сировинної бази промисловості, досліджували можливості ефективного використання мінеральних ресурсів Придніпров 'я тощо.

Великих успіхів досягла наукова діяльність фахівців факультету. Серед проблем, що їх успішно досліджували на геофаку (разом із провідними фахівцями Інституту геології ДДУ), тут комплексно вивчали Південноукраїнський марганцеворудний басейн (В. І. Грязнов), залізорудні родовища в Криму i Приазов $\dddot{1}$ (А. І. Літвиненко), корисні копалини Придніпров `я і Західного Донбасу (Н. 3. Хмарський, М. М. Ільвицький, Г. М. Романенко). Вже в ті роки розпочали вести фундаментальні біостратиграфічні і палеогеографічні дослідження мезо-кайнозойських відкладів Південної України у зв 'язку з державним геологічним картографуванням і пошуками корисних копалин (М. Ф. Носовський). Одночасно науковці геофаку досліджували проблеми енергетичного освоєння р. Дніпро, виконували великі гідрогеологічні дослідницькі роботи, пов язані з проектуванням Каховської, Дніпродзержинської, Кременчуцької та Канівської ГЕС, каналу Дніпро - Донбас, Дніпровської зрошувальної системи тощо.

Скрутні часи для факультету настали на початку 1960-х років, коли через створення нового фізико-технічного факультету була припинена діяльність низки факультетів, до яких і потрапив геолого-географічний. У 1960 році геолого-географічний факультет ліквідовано, навчання студентів припинене. Кафедри геологічного напрямку були розформовані, а кафедру географії переведено до історико-філологічного факультету, з 1971 р. - до історичного факультету, з 1976 р. - до економічного факультету (готувала лише спеціалістів заочної форми навчання).

За ініціативи М. Ф. Носовського (тоді проректор 3 наукової роботи ДДУ) було відкрито в 1977 р. геологічне відділення при хімічному факультеті ДДУ для навчання двох груп студентів за фахом «Гідрогеологія та інженерна геологія». Першою у 1977 році було створено кафедру геології (зав. проф. М. Ф. Носовський), другою, у 1980 році - кафедру гідрогеології та інженерної геології (зав. проф. I. А. Скабаланович).

Кістяк новостворених кафедр склали провідні співробітники геологічної галузі та Інституту геології ДДУ (І. С. Данілов, І. М. Барг, Н. Ф. Дудник, Г. В. Пасічний, В. М. Нагорний, Г. П. Євграшкіна, Н. Г. Коваленко, Ю. Д. Шковира, В. Т. Осауленко, А. Я. Туровська та ін.). У 1986 році кафедра фізичної та економічної географії (зав. проф. Г. В. Пасічний, доценти Л. І. Зеленська, А. П. Дьоміна, В. П. Коростік, ст. викл. П. С. Дінець та ін.) у складі новоствореного в університеті педагогічного факультету набрала перших студентів-географів (25 осіб) денної форми навчання.

Відродження геолого-географічного факультету відбулося у вересні 1990 року (наказ № 1059 від 09.08.1990 «Про створення в Дніпропетровському держуніверситеті геолого-географічного факультету та навчально-наукового комплексу «Геокомплекс»). Біля витоків новоствореного факультету стояли проф. Г. В. Пасічний, доц. В.В.Богданович, І. С. Данілов, I. М. Барг. Саме цим постатям, їх наполегливій i цілеспрямованій діяльності геолого-географічний факультет зобов 'язаний своїм другим народженням.

На чолі факультету, що складався із трьох кафедр, став відомий в Україні палеогеограф, д. географ. н., проф. Григорій Васильович Пасічний, автор та співавтор понад 20 монографій, атласів, навчальних посібників та 10 навчально-методичних розробок. Свою наукову діяльність професор пов'язував із проблемами геологіi, геоморфологіі, палеогеографії та 


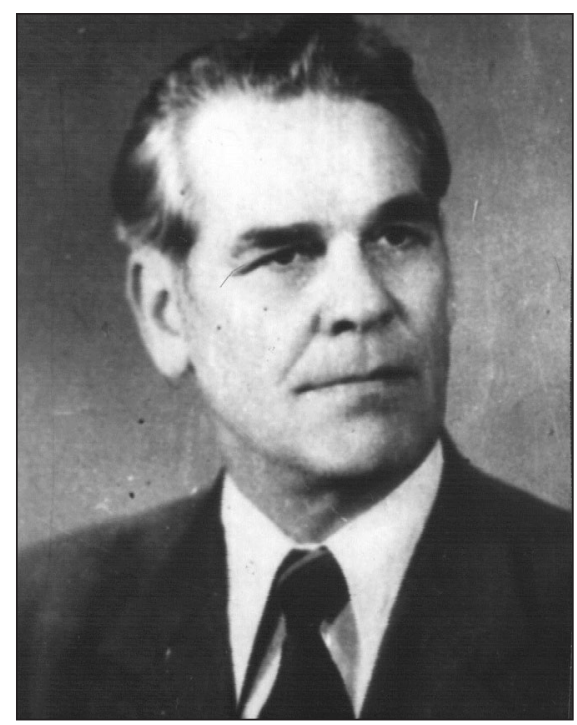

Д-р геол.-мін. наук, проф., заслужений діяч науки і техніки України Носовський Михайло Федорович (1921-2008)

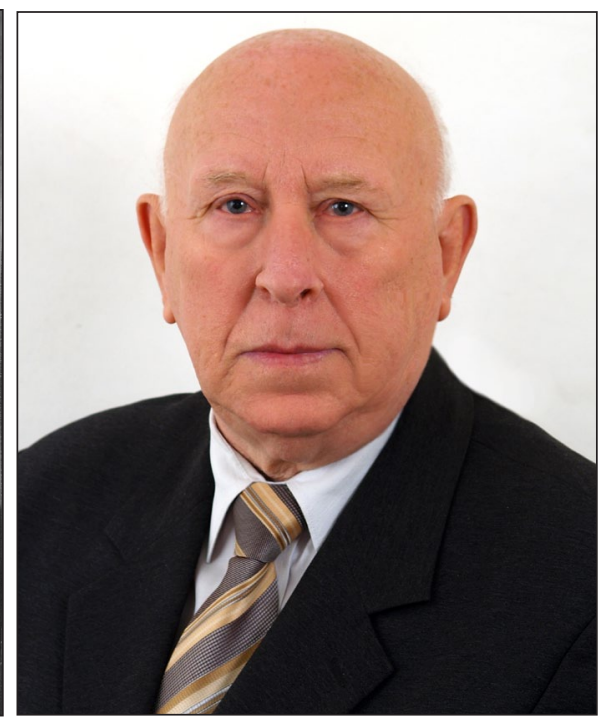

Д-р геол.-мінерал. н., проф., заст. декана з наукової роботи факультету Барг Ігор Мусійович (1935-2011)

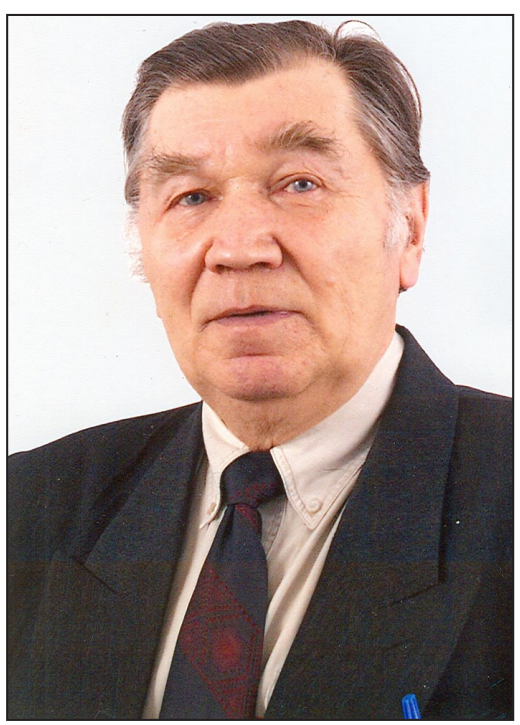

Д-р геогр. н., проф., перший декан факультету з 1990 по 1999 рік Пасічний Григорій Васильйович (1932-2003) геоекології. За його участі відкрито кілька родовищ корисних копалин в Україні. Складені ним карти по півдню України більшості віків неогену увійшли основною частиною до Атласу палеогеографічних карт Центральної і Східної Свропи. Г. В. Пасічний був великим спеціалістом-геологом, палеогеографом, який вніс вагомий внесок у розвиток української геологічної науки і пізнання геологічної будови України.

У 1989 році кафедру геології очолив к. г.-м. н., доц. В.В. Богданович, а кафедру гідрогеології - к. т. н., доц. В. Т. Осауленко. Через рік нового існування на ГГФ відбулися певні реорганізації. Через складну екологічну ситуацію в Придніпров “̈ та завдяки необхідності у підготовці фахівців з охорони навколишнього середовища на факультеті в 1991 році організовано першу в Україні кафедру геоекології та раціонального використання природних ресурсів із статусом випускової. Завідувачем призначено проф. Г. В. Пасічного. На чолі кафедри фізичної та економічної географії з 1991 р. стала к. г. н., доц. Л. І. Зеленська, відомий нині в Україні фахівець у галузі методики викладання географіï. У 2000 році вона з успіхом захистила докторську дисертацію. Дві геологічні кафедри у цьому ж році були об єднані в одну загальну кафедру геології та гідрогеології на чолі $з$ к. г.-м. н., доц. В. В. Богдановичем, потім к. г. н., доц. Н. П. Шерстюк.

Із квітня 1999 року деканом геолого-географічного факультету був призначений відомий фахівець у галузі мінералогії, дослідник Нікопольського марганцеворудного басейну, к. г.-м. н., проф. Володимир Володимирович Богданович.
Деякі кардинальні зміни в організаційній структурі факультету відбулися і на початку XXI століття. Через укрупнення біологічного факультету і створення там потужного навчального екологічного центру йому було надано право готувати фахівців-екологів в університеті, і постало питання про перепрофілювання кафедри геоекології на підготовку студентів-гідрологів, які були вкрай потрібні Дніпропетровському промисловому регіону. Організацією цієї важкої справи займалися колишні завідувачі кафедрою д. т. н., проф. В. Г. Пасічний (син Г. В. Пасічного), к. б. н., доц. Л. В. Доценко і д. г. н., доц. Н. П.Шерстюк.

Iз 2015 року геолого-географічний факультет очолює фахівець у сфері гідрології та хімічного складу поверхневих вод, д. г. н., проф. Наталія Петрівна Шерстюк. Завідувачі кафедри географії д. пед. н., проф. Л. І. Зеленська (з 1991), кафедри геології та гідрогеології д. геолог. н., проф. Г. П. Свграшкіна (з 2012), кафедри гідрології та геоекології к. г. н., доц. Д. О. Довганенко (з 2015).

Кафедра геології та гідрогеології уособлює історію та сучасність геолого-географічного факультету. Нині тут працюють видатні та відомі вчені України та молоді науковці. Всі викладачі кафедри мають наукові ступені та відповідні вчені звання. Основні наукові напрями очолюють доктори геологічних наук Г. П. Свграшкіна та Т. П. Мокрицька. Під їх керівництвом вирішуються складні та актуальні питання техногенної гідрогеології та інженерної геології. Один із напрямів досліджень, що має міжнародне визнання, - це охорона геологічних пам’ яток (керів- 


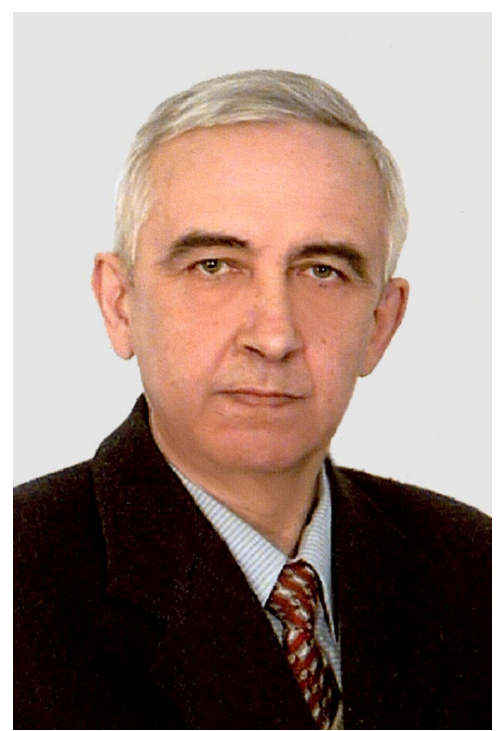

К. г.-мін. н., проф., другий декан факультету

з 1999 по 2015 рік

Богданович

Володимир Володимирович

(нар. 1948 р.)

ник - доц. В. В. Манюк) у рамках проекту ProGeo. Класичні геологічні та стратиграфічні дослідження, які заснували професори М. Ф. Носовський та I. М. Барг, продовжують доценти О. В. Бондар та Т. А. Стефанська. За останні п'ять років науковці кафедри опубліковали дві монографії, п’ять статей у міжнародних наукових виданнях, що зареєстровані у науковометричних базах, понад 20 статей у провідних наукових виданнях України.

Кафедра фізичної та економічної географії - найбільша на факультеті, навчальний процес забезпечують 1 професор, доктор педагогічних наук та дев ять доцентів, кандидатів наук. Кафедра $є$ центром діяльності Дніпропетровського відділення Українського географічного товариства й Української картографічної асоціації; регіональним науковим центром із проблематики географічного краєзнавства і туризму, методики навчання географії. Фахівці кафедри проводять дослідження з актуальних сучасних напрямів, таких як геоінформаційне й атласне картографування, математико-картографічне моделювання, інноваційні технології навчання, урбаністика, політична географія, географія Всесвітньої спадщини, рекреаційна географія, географічне краєзнавство тощо.

Фахівці кафедри брали активну участь у розробленні генерального плану Національного історико-культурного заповідника «Хортиця», схеми перспективного розширення мережі природнозаповідного фонду Дніпропетровської області, укладанні схем зонування і планування новостворюваних національних природних парків - Орільського і Самарський Бір (доц. В. В. Манюк). У 1994 і 1997 роках кафедра одержала гранти Міжнародного фонду «Відродження» для видання екологічного і медикоекологічного атласів Дніпропетровської області. Провідні викладачі кафедри за останні 10 років видали низку монографій, навчальних посібників та підручників, як вузівських, так і призначених для використання у загальній середній школі (Л. І. Зеленська, В. В. Безуглий, Н. М. Дук). Із 2004 по 2012 рік на кафедрі щорічно проводили Міжнародну наукову конференцію студентів і аспірантів, у роботі якої брали активну участь представники 3 понад 25 країн світу. Тісні наукові зв 'язки кафедра підтримує із провідними вузами Азербайджану, Австрії, Білорусі, Казахстану, Киргизії, Німеччини, Польщі, Росії, Румунії та ін. Протягом останніх років кафедра фізичної та економічної географії систематично приймає іноземні студентські делегації з університетів Інсбрука (Австрія), Грайсфальда та Дуйсбург-Ессена (Німеччина), Могильова (Білорусь) та організує 3 ними спільні експедиційні дослідження і наукові екскурсії. Також науковці кафедри періодично запрошують провідних іноземних фахівців для читання лекцій студентам-географам ДНУ.

Кафедра гідрометеорології та геоекології проходить етап формування напрямів наукових досліджень. Поряд із класичною науковою тематикою гідрології та гідрохімії проводяться гідроекологічні, гідробіологічні та інші дослідження, пов'язані з проблемами охоро-

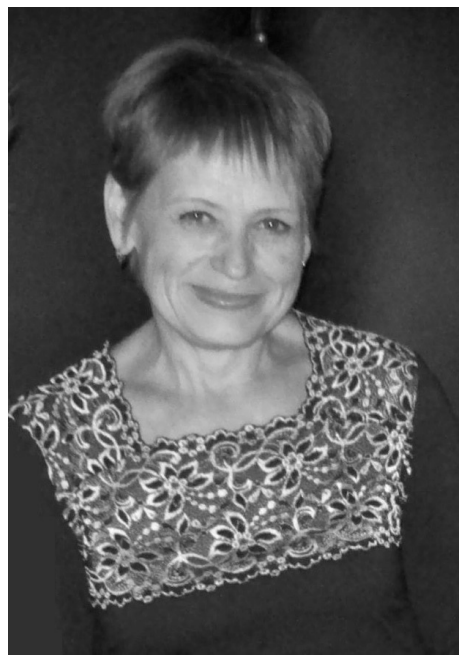

Д. геогр. н., проф., третій декан факультету i3 $2015 \mathrm{p}$. Шерстюк Наталія Петрівна

ни та раціонального використання водних ресурсів. Складну гідроекологічну ситуацію, що існує у Середньому Придніпров 'ї, вивчають у межах гідрологічного та гідрохімічного напряму, який очолює д. геогр. н. Н. П. Шерстюк. Важливі питання стану, аналізу та прогнозу метеорологічних умов урбанізованих територій вирішуються під керівництвом доц. А. С. Горба. Невід'ємною складовою біотехносфери регіону є «жива речовина», яка змінюється сама $\mathrm{i}$ змінює гідролого-гідрохімічні умови водних об'єктів. Саме ці важливі закономірності досліджує група науковців під керівництвом доц. Л. В. Доценко. За останні п'ять років науковці кафедри надрукували дві монографії, дві статті у міжнародних наукових виданнях, зареєстрованих у науковометричних 
базах, понад 15 статей у провідних наукових виданнях України. Результати наукових досліджень постійно доповідаються на наукових конференціях всеукраїнського та міжнародного рівнів, особистих зустрічах із провідними фахівцями України.

У цілому активна наукова діяльність викладачів кафедр геолого-географічного факультету дозволяє проводити навчання студентів на сучасному рівні 3 урахуванням потреб регіону та України.

Стійкий розвиток геолого-географічного факультету додає впевненості у подальшому його процвітанні у складі Дніпропетровського національного університету імені Олеся Гончара.

\section{Бібліографічні посилання}

Prisniakov, V.F. (Ed.), 1993. Istoria Dnipropetrovskogo universiteta. [History of Dnipropetrovsk University]. Dnepropetrovsk: DDU, $240 \mathrm{p}$.

Polyakov, M.V. (Ed.), 2008. Istoria Дnipropetrovskogo nasionalnogo universiteta. [History of Dnipropetrovsk National University]. Dnepropetrovsk: DNU, 308 p.

Надійшла до редколегії 25.02.2016 